\title{
The Stolpen Volcano in the Lausitz Volcanic Field (East Germany) - volcanological, petrographic and geochemical investigations at the type locality of basalt
}

\author{
Olaf TIETZ1* , Jörg BÜCHNER', Manuel LAPP², Thomas SCHOLLE \\ ${ }^{1}$ Senckenberg Museum of Natural History Görlitz, Am Museum 1, 02826 Görlitz, Germany; olaf.tietz@senckenberg.de \\ ${ }^{2}$ Saxon State Office for Environment, Agriculture and Geology (LfULG), Halsbrücker Straße 31a, 09599 Freiberg, Germany \\ ${ }^{3}$ Engineering Office, Kirschallee 1, 01833 Stolpen, Germany \\ * Corresponding author
}

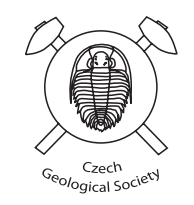

The 30 Ma Stolpen Volcano near Dresden (Saxony) is situated at the western margin of the Lausitz Volcanic Field. It forms a small isolated basaltic hill, the famous Stolpen Castle Hill, penetrating the granodioritic basement of the Lausitz Block and is worldwide the type locality for the term 'basalt', as coined by Agricola (1546). The volcano has always been interpreted as subvolcanic crypto- or lava dome.

New geological mapping, dip measurements of the basaltic columnar jointing and the first evidence of scoria for the Stolpen Volcano allow for a new interpretation of the volcanic edifices. On this basis the structure is best described as a maar crater volcano filled by a $110 \mathrm{~m}$ thick basanitic lava lake. According to genetic classification, it is a complex monogenetic volcano formed in three phases: (1) a phreatomagmatic diatreme phase with a maar crater, (2) a scoria cone phase with the final basanitic lava lake filling, and (3) a post-volcanic phase with neotectonic uplift, denudation and exposure of a basaltic hill since c. 1.3 Ma. The volcano reconstruction indicates an ongoing change in the eruption style from phreatomagmatic (phase 1) to eruptive and, finally, effusive processes (phase 2) without significant gaps between the eruption episodes. The only difference appears to be caused by a variable water supply during the magma ascent and volcanic eruption.

New mineralogical (QAPF) and geochemical (TAS) investigations of the Stolpen lava samples reveal that the Stolpen Hill is not built by a basalt, but basanite trending toward a nephelinite, following the current nomenclature. Microscopic analyses also provide evidence of magma mingling, such as nephelinite melt enclaves, and show local lava contamination by the country-rock granodiorite, also supported by the presence of quartz xenocrysts. The combined field observations, petrography and geochemical data indicate overall heterogeneity of the Stolpen lava. Therefore, the Stolpen Castle Hill is not - in a scientific sense - a suitable type locality for either basalt or basanite. However, the outcropping volcanic rocks as well as their scientific and historical importance undoubtedly give relevance to Stolpen as a type locality for basaltic volcanic rocks in a broader sense.

Keywords: maar-diatreme volcano, basanite, monogenetic volcanism, Cenozoic landscape evolution, basalt locus typicus, magma mingling Received: 3 March 2018; accepted: 6 December 2018; handling editor: T. Magna

The online version of this article (doi: 10.3190/jgeosci. 275) contains supplementary electronic material.

\section{Introduction}

The Stolpen Castle Hill is renowned worldwide for being the type locality of the rock 'basalt' following the first historical note by Agricola (1546). For this reason, the locality was chosen as the German national geotope in 2006 (Goth and Suhr 2007). The long history of geological research at the Stolpen Volcano is outlined in more detail in Büchner et al. (2017) and the editorial of this issue (Tietz and Büchner 2018). Also important for the present study are the works of Geinitz (1882), Klemm (1890, 1892), August Herrmann Eulitz (in Theile 1884) and Koch et al. (1983). In their work, Geinitz (1882) and Klemm $(1890,1892)$ gave information on the orientation of basaltic columnar joints and described up to $1 \mathrm{~m}^{3}$ or
$1.5 \mathrm{~m}$ large granodiorite xenoliths in the basaltic lava. Additionally, Klemm (1890) compiled the first detailed geological map of the Stolpen Volcano. Geinitz (1882) and Klemm $(1890,1892)$ interpreted the Stolpen Hill as a volcanic plug in the granodiorite basement with broad SW-NE oriented feeder dyke and a mushroom-like top. One notable outcrop is the castle well with a depth of $84.4 \mathrm{~m}$ (Büchner et al. 2017). The well is situated at the highest point of the hill and penetrates exclusively basaltic lithology, reaching more than $50 \mathrm{~m}$ below the level of the surrounding granodiorite country rock (Klemm 1892). A historical line drawing made by the mine foreman August Herrmann Eulitz illustrates the orientation of the basaltic columns over the entire length of the well (Theile 1884). The precise drawing shows 
that the columnar jointing constantly dips steeply towards SSE, but undergoes a slight change in inclination. While at the top dipping angles start at $75^{\circ}$, they gradually rotate to $72^{\circ}$ in the middle and $60^{\circ}$ at the base of the well.

Koch et al. (1983) published a wealth of new fabric measurements and geomagnetic mapping data, interpreting the Stolpen Volcano as a crypto- or lava dome ("Staukuppe” or "Quellkuppe”), implying a broadly subvolcanic origin. At the time this interpretation was a very common model for basaltic volcanoes and was supported by the significantly lowered position of the basaltic lava body compared to the level of the granodiorite country rock observed in the Stolpen Castle well. Additionally, Koch et al. (1983) presented four whole-rock geochemical analyses and a detailed petrographic thin section description. According to these microscopic data, the Stolpen lava is olivine-augite basalt with minor nepheline and glass because clinopyroxene and plagioclase dominate over olivine. Nepheline and volcanic glass constitute less than 5 vol. \% of the groundmass.

Scholle (1994-2017) has documented over 90 different local outcrops in the Stolpen Castle and town area. In total, 42 street and house excavation pits, 29 house basements with outcropping bedrock and 23 rock cliffs, some of which were only temporarily visible, situated on private land and/or built into houses, streets and walls, were documented. This outcrop collection forms an important basis for the present study. The aim of the study is to verify previous data and, with the help of new dating work, to develop a modern reconstruction of the Stolpen Volcano. Based on this reconstruction, the post-volcanic landscape evolution is described.

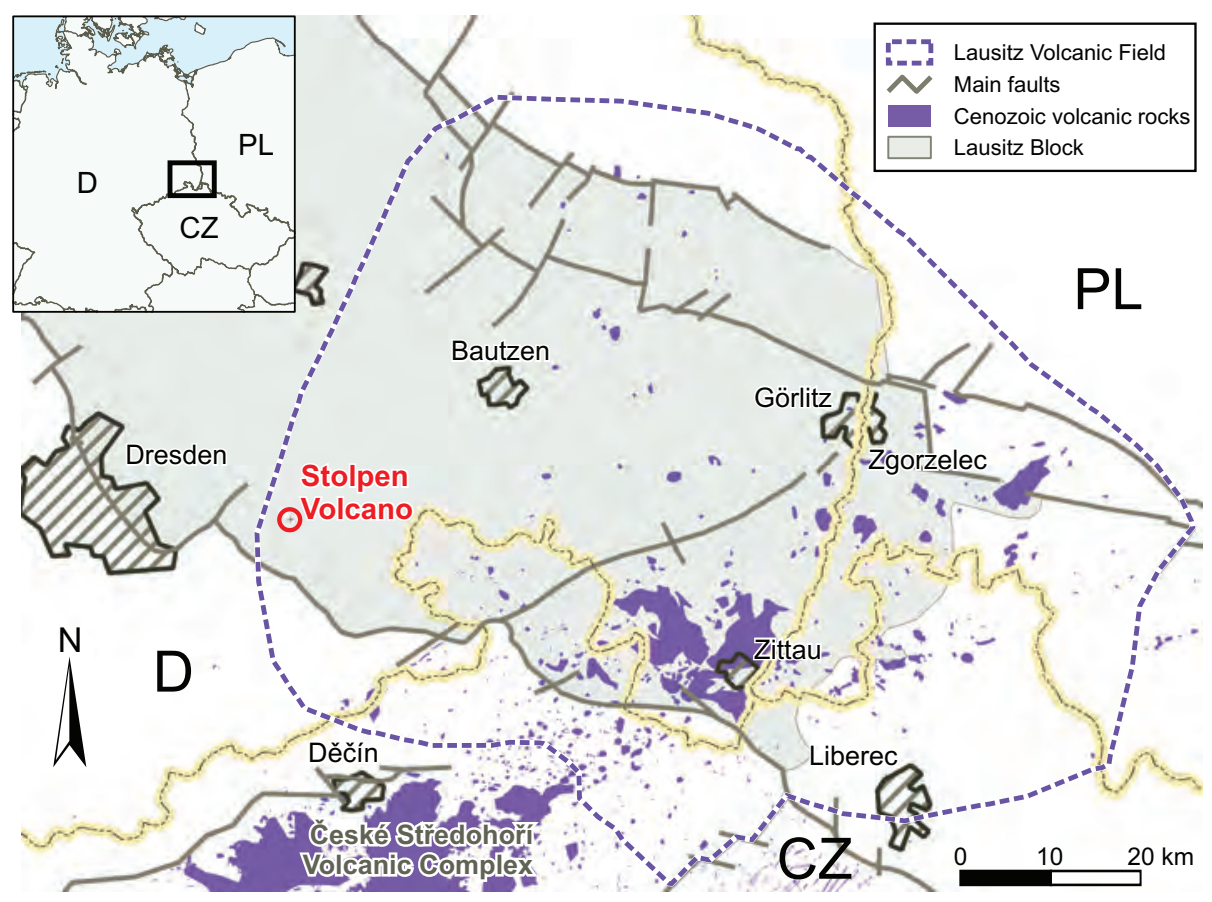

\section{Geological setting}

The Stolpen Volcano (Saxony) occurs at the westernmost margin of the Lausitz Volcanic Field (Büchner et al. 2015) belonging the Cenozoic Central European Volcanic Province (Fig. 1). Today the volcano represents a conspicuous isolated peak $25 \mathrm{~km}$ east of Dresden in an otherwise rolling landscape, composed of granodiorite. A famous medieval castle sits atop the hill that is elevated $40-90 \mathrm{~m}$ above the surroundings (Fig. 2). The basement consists of a Cadomian two-mica granodiorite with an age of c. 540-530 Ma (Tikhomirova 2002). The age of the Stolpen basalt was determined at $25.3 \pm 0.5 \mathrm{Ma}$ by $\mathrm{K}-\mathrm{Ar}$ dating (Pfeiffer et al. 1984), but Ar-Ar age determinations in the Lausitz Volcanic Field suggest an older age of $c$. $30 \mathrm{Ma}$ (Büchner et al. 2015). Typical rocks of the Lausitz Volcanic Field are primitive "basalts" (basanite, tephrite and nephelinite) as well as differentiated rocks (phonolite and trachyte). Primitive magmas typically produced scoria cone volcanoes or, less commonly, maar-diatreme volcanoes, whereas evolved rock lithologies formed crypto- or lava domes. At present, large parts of the volcanic edifice are eroded and only remnants of the massive lava rocks, such as lava lakes, lava flows, dykes, plugs and domes are mainly found as hills and ridges.

The investigated area is a part of the Lausitz Block, a block-fault mountain and uplift area which dates back to 92 Ma (Janetschke et al. 2015). The main uplift took place between 85 and $50 \mathrm{Ma}$, what caused denudation of c. 3,000-3,500 m (Lange et al. 2008; see also Hofmann et al. 2018). Tietz and Büchner (2015) used volcanic edifices and related Quaternary deposits to determine the younger uplift und denudation history of the Lausitz Block, demonstrating an uplift of up to

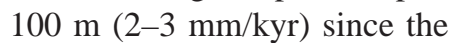
volcanism at $30 \mathrm{Ma}$. These neotectonic movements started at 1.3 Ma with a climax at $320 \mathrm{ka}$, following the Elsterian Glaciation (e.g., Wenger et al. 2017).

\section{Methods and materials}

\subsection{Volcanology}

The remnants of the Stolpen Volcano are only visible in a few places. Large areas are

Fig. 1 Overview of the Lausitz Block and extent of the Lausitz Volcanic Field with the position of the Stolpen Volcano (modified from Büchner et al. 2015). 


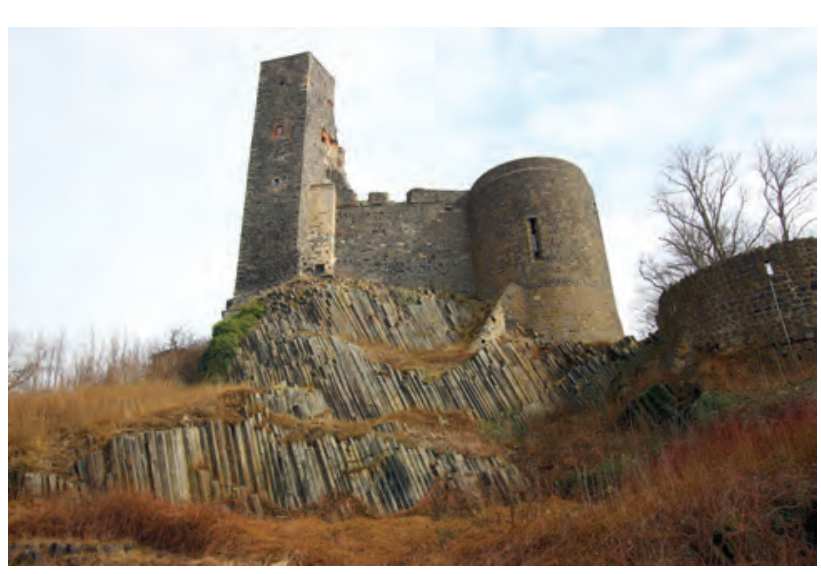

Fig. 2 View to the abandoned quarry at the WSW edge of the Stolpen Castle Hill with basaltic columns. The columnar jointing shows a clear periclinal structure. The outcrop is about $40 \times 15 \mathrm{~m}$ in size. See Fig. 6 for location.

covered by the residential area of Stolpen and the medieval castle. Only a handful of basaltic cliffs exist around and inside the Stolpen Castle, most with regular-shaped columnar jointing. The careful evaluation of results from the existing literature as well as the use of the unpublished mapping data (Scholle 1994-2017) were important for the new geological mapping. These data are complemented by new measurements of the basaltic column orientations from 18 localities. Column orientation was determined using 49 compass measurements of linear structures. Additionally, house basement outcrops documented by Scholle (1994-2017) were examined by the deepening of shallow drill holes and volcanologically important samples, in particular pyroclastic rocks, were collected. Unfortunately, the use of the digital elevation model (DEM, $2 \mathrm{~m}$ horizontal resolution, $0.01 \mathrm{~m}$ vertical resolution) was not helpful for the geological mapping due to extensive anthropogenic modification of the hill shape following the construction of the castle (fortification walls and houses) and the opening of basalt quarries on the hill flanks. All sample localities and measurement points were recorded by GPS. Maps were produced using geographic information system (GIS; ESRI software ArcGis10.5 and the map sources of the Staatsbetrieb Geobasisinformation und Vermessung Sachsen, GeoSN).

\subsection{Petrography and mineral chemistry}

Seven least altered basaltic lava samples were collected from cliff outcrops for petrographic and whole-rock geochemical analysis. In summary, six newly produced polished thin sections and 44 historical thin sections from the archive of the Saxon State Office for Environment, Agriculture and Geology Freiberg (mainly from the late $19^{\text {th }}$ century) were investigated for petrography using an optical polarizing microscope Leica DM2500P.
Mineral classification was supported by a standard-free chemical analysis by energy-dispersive X-ray spectroscopy (EDX, Bruker xFlash Detector 410-11) using a Jeol JSM-6510LV scanning electron microscope (SEM) on six polished thin sections. The groundmass was studied in detail with SEM-EDX to determine nepheline or plagioclase occurrence.

\subsection{Whole-rock geochemistry}

Five newly collected whole-rock samples were analysed to quantify the content of major and selected trace elements.

Two of them (samples 15/9/3-8, 15/9/3-9) were analysed by wavelength-dispersive X-ray fluorescence spectrometry (XRF) at the Institute for Geological Sciences, the University of Jena, using a Philips PW 2400 spectrometer and applying standard techniques (Vogel and Kuipers 1987). Analyses of the major elements were carried out on lithium borate fused glass beads (Spectromelt A12, Merck) and trace elements on pressed powder pellets (Wax C, Hoechst). The international reference basalt JB-3 (Geological Survey of Japan) was used for calibration and data quality control.

Three of the whole-rock samples (17/1/31-2, 17/3/14-1, 17/4/21-1) were crushed, and analysed by Bureau Veritas Laboratories (BVML) Vancouver, Canada. The major oxides were measured by XRF (Panalytical Axios) and trace elements, including the rare earth elements, by inductively-coupled plasma mass-spectrometry (ICPMS Perkin Elmer Elan) after a lithium-borate fusion and acid digestion of $c .0 .2 \mathrm{~g}$ pulp (analytical packages LF200 and AG200). Estimated analytical detection limits were $0.01 \mathrm{wt}$. \% for major oxides (only $\mathrm{Fe}_{2} \mathrm{O}_{3}=0.04$ wt. \%) and 0.01-8 ppm for trace elements. In-house analyses were conducted in accordance with internal and international standards including DS10, GS311-1, GS910-4, OREAS45EA. Loss on ignition was assessed by sintering at $1000^{\circ} \mathrm{C}$. In addition, five major-element analyses from Koch et al. (1983, their tab. 9.1) were also considered.

\section{Results}

\subsection{Volcanology}

Based on the aforementioned temporary outcrop data (Scholle 1994-2017), a geological map of the Stolpen Volcano with a scale of $1: 10,000$ was produced (Fig. $3)$. Unfortunately, the contact between the basaltic lava and the granodioritic country rock could not be observed. Furthermore, $\sim 0.5-2.0 \mathrm{~m}$ thick Pleistocene basaltic boulder debris covered the geological struc- 


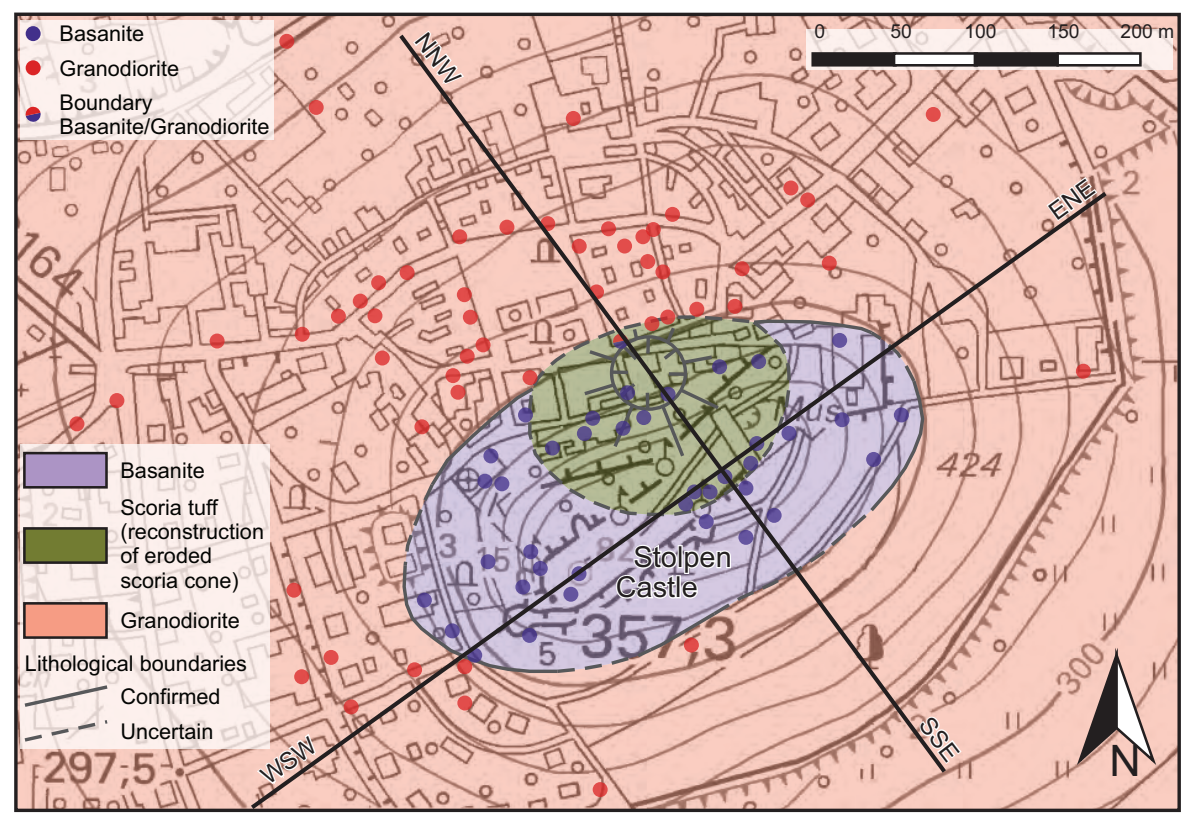

Fig. 3 Geological map of the Stolpen Volcano structure with used outcrop localities (dots) and the positions of the cross sections (Fig. 11). Green color denotes the presumed occurrence of the meanwhile eroded or by basanite lava overlapped scoria cone. tures significantly (Schubert 1972; Scholle 1994-2017), masking the bedrock boundaries. Nevertheless, the boundary between the basaltic volcano structure and the granodioritic country rock could be quite accurately determined in most cases due to the proximity of basaltic and granodioritic outcrops (Fig. 3). Only the south-eastern contact could not be pin-pointed due to an insufficient number of outcrops. This area has been extensively modified by ancient quarries and therefore lacks natural morphological features.

The new geological map varies slightly from that of Klemm (1890). The distribution of basalt in the previous map is more pear-shaped and isometric, whereas in the new one, the outcropping basaltic area is rather oval with a clear WSW-ENE elongation. The dimensions of the newly mapped basaltic outcrop are $340 \times 180 \mathrm{~m}$, whereas the boundary roughly coincides with the $320 \mathrm{~m}$ contour line described by Geinitz (1882). Only in the south-east does the boundary occur higher than predicted, at $325 \mathrm{~m}$ a.s.l. In the south-west part it lies at $315 \mathrm{~m}$ a. s. l. (Fig. 3).

An important discovery during mapping has been the observation of an ash-dominated tuff with basaltic scoria lapilli and bomb inclusions. This pyroclastic rock deposit was only found at one locality in the basement of a house on Stolpen market place (corner to Schloßstraße). A small gap in the building stone wall offers a window to the bedrock that lies directly behind the southern cellar wall, $3.5 \mathrm{~m}$ below the street level (Fig. 4a). The exposed tuff shows reddish brown colours, is intensively altered, contains scoria clasts 1-20 cm in size with a roughly oval shape (Fig. 4b) and includes some rather small granodioritic xenoliths. The non-bedded ash-tuff matrix dominates the rock, with matrix-supported inclusions making up 30-40 vol. \%. The mostly rounded vesicles in the basaltic scoriae $(0.2-3.0 \mathrm{~mm}$ in diameter $)$ constitute up to $50 \mathrm{vol}$ \% (Fig. 4c). In the northern part of the house cellar, a flat in situ granodioritic rock spur exists mere $8.7 \mathrm{~m}$ away from the scoria tuff outcrop and marks the currently closest known contact between volcanic structure and host rock. The map shows the hypothetical distribution of the entire scoria cone (Fig. 3); today most parts of the scoria cone have been eroded.

Scoria fragments (lapilli up to bombs) were also found as isolated inclusions in the basaltic lava with the largest diameters of 1 to $10 \mathrm{~cm}$ (mean value $4.5 \pm 2.2 \mathrm{~cm}$, $\mathrm{n}=37$; Fig. 5, ESM 1). Such inclusions are occasionally clustered together, particularly in basaltic building blocks, but also in basaltic bedrock cliffs. The vesicles have a diameter of $0.1-22 \mathrm{~mm}$ with an average size of $0.3 \mathrm{~mm}$ for small vesicles and $5.5 \mathrm{~mm}$ for large vesicles (all together: $\mathrm{n}=32$ ). Bulk vesicularity is relatively high at $~ 35-65 \%$ (mean $=48.5 \%, n=33$ ). The shape of large vesicles ( $>1.4 \mathrm{~mm}$ ) is mainly convoluted and irregular, but sometimes also subspherical. Noteworthy is a bimodal distribution of vesicle sizes with mean diameters of $0.3-0.9 \mathrm{~mm}$ (min- $\max =0.1-2.0 \mathrm{~mm}$ ) and 1.4-5.5 mm (min-max $=0.5-22.0 \mathrm{~mm}$ ); the larger bubbles predominate significantly in volume and number. The occurrence of pyroclasts indicates a subaerial nature of the Stolpen Volcano and is therefore important in volcano reconstruction.

Our measurements of basaltic column orientations (ESM 2, Fig. 6) are similar to those of Geinitz (1882, plate V, fig. 4) and Koch et al. (1983, plate X, fig. 10.30). The arrows that indicate linear projection of the columnar jointing show fairly clearly a radial, outwards-orientated dipping pattern, originating in the center of the basaltic hill. This indicates that the base of the basaltic lava body 

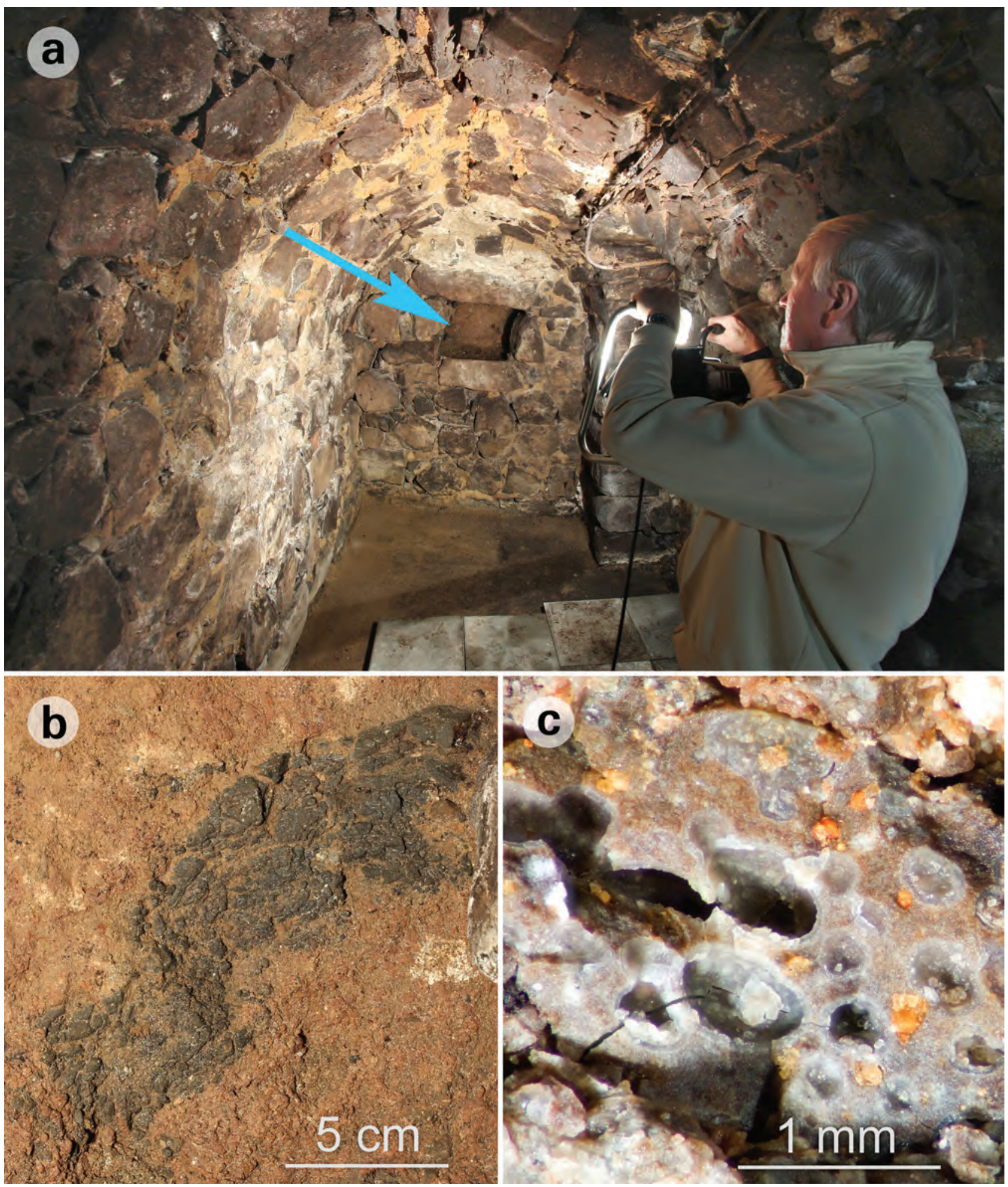

Fig. 4 A scoria tuff outcrop in the cellar at Stolpen, Schloßstraße 1: a - Blind window in the southern cellar wall $($ arrow, size $=0.5 \times 0.5 \mathrm{~m})$. b - Reddish brown argillaceous tuff with basaltic scoria bomb. Detail from Fig. 4a. c - Macro-photograph from an intensely altered scoria clast in scoria tuff. Vesicles are filled with secondary mineral margins (translucent, light gray). Altered olivine phenocrysts (orange dots) and lava (reddish brown). See Fig. 4a for location.

must have a bowl-shaped contact surface (DeGraff and Aydin 1987). The tilting axis of the convergent basaltic columnar structure (the dashed line; Fig. 6) runs longitudinally to the basaltic distribution from SW to NE. 

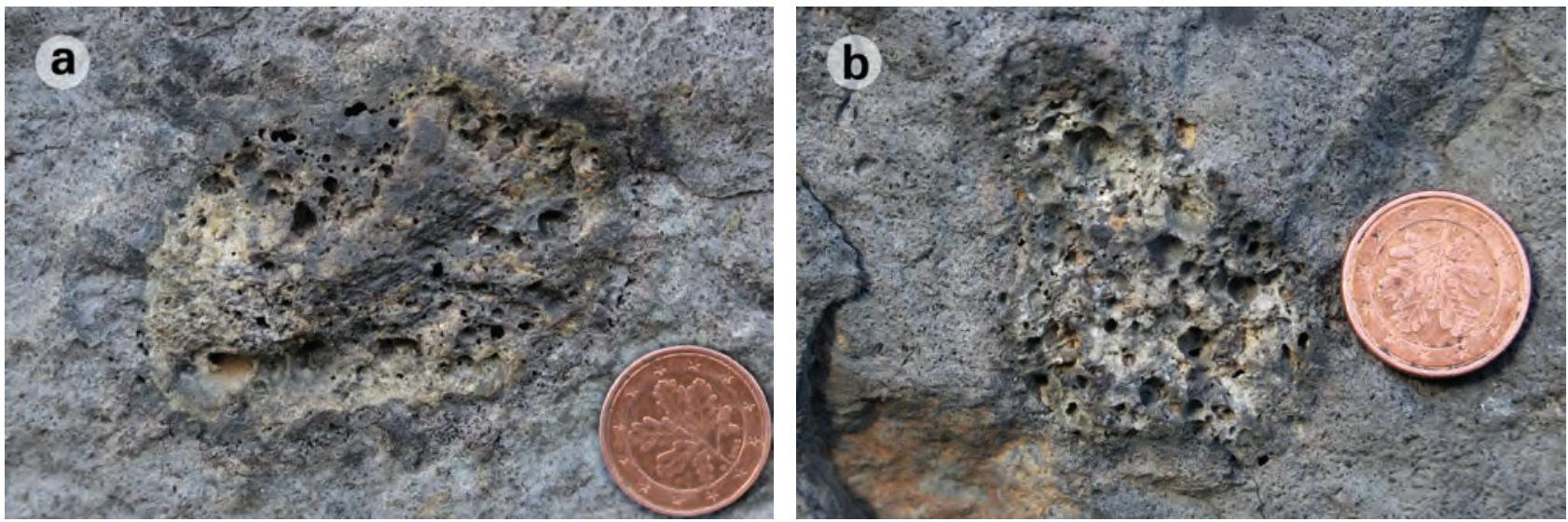

Fig. 5 Scoria inclusions in the Stolpen lava. Rock surfaces from building stone walls at the $1^{\text {st }}$ castle courtyard. Coin diameter is $15 \mathrm{~mm}$. a - Eastern facade of Kornhaus/Hauptwache (cashpoint); $\mathbf{b}$ - Northern inner castle wall.

However, around the recent hill ridge, the tilting axis is rather shifted to the northern side of the Castle Hill (Fig. 2). One possible explanation is that former basalt mining activities have changed the symmetry of the original mountain ridge. The flattest dipping columnar joints were measured at the north-western margin, near the contact to the granodioritic country rock, $30^{\circ}$ at the northernmost basal bench of the western quarry and $25^{\circ}$ in the basement of the house at Markt 22. These values coincide with those of Geinitz (1882), who also described minimal columnar dipping angles of 15 to $40^{\circ}$ at the north-western margin.

\subsection{Petrography and classification}

Investigation of 50 thin sections indicates that all samples have a porphyritic to microcrystalline texture (Fig. 7). Phenocrysts are relatively limited in volume (10-30 \%) and small in size (maximum of $1.5 \mathrm{~mm}$ ). Clinopyroxene is the major constituent of phenocrysts, followed by olivine. In most of the investigated samples $(n=43)$, clinopyroxene, plagioclase and opaque minerals occur as microliths $(<0.1 \mathrm{~mm})$. Nepheline and glass are observed in the groundmass, appearing in various amounts, mostly as interstitial fillings between microliths. These represent the final phase of magma crystallization. The rare mantle xenoliths are small

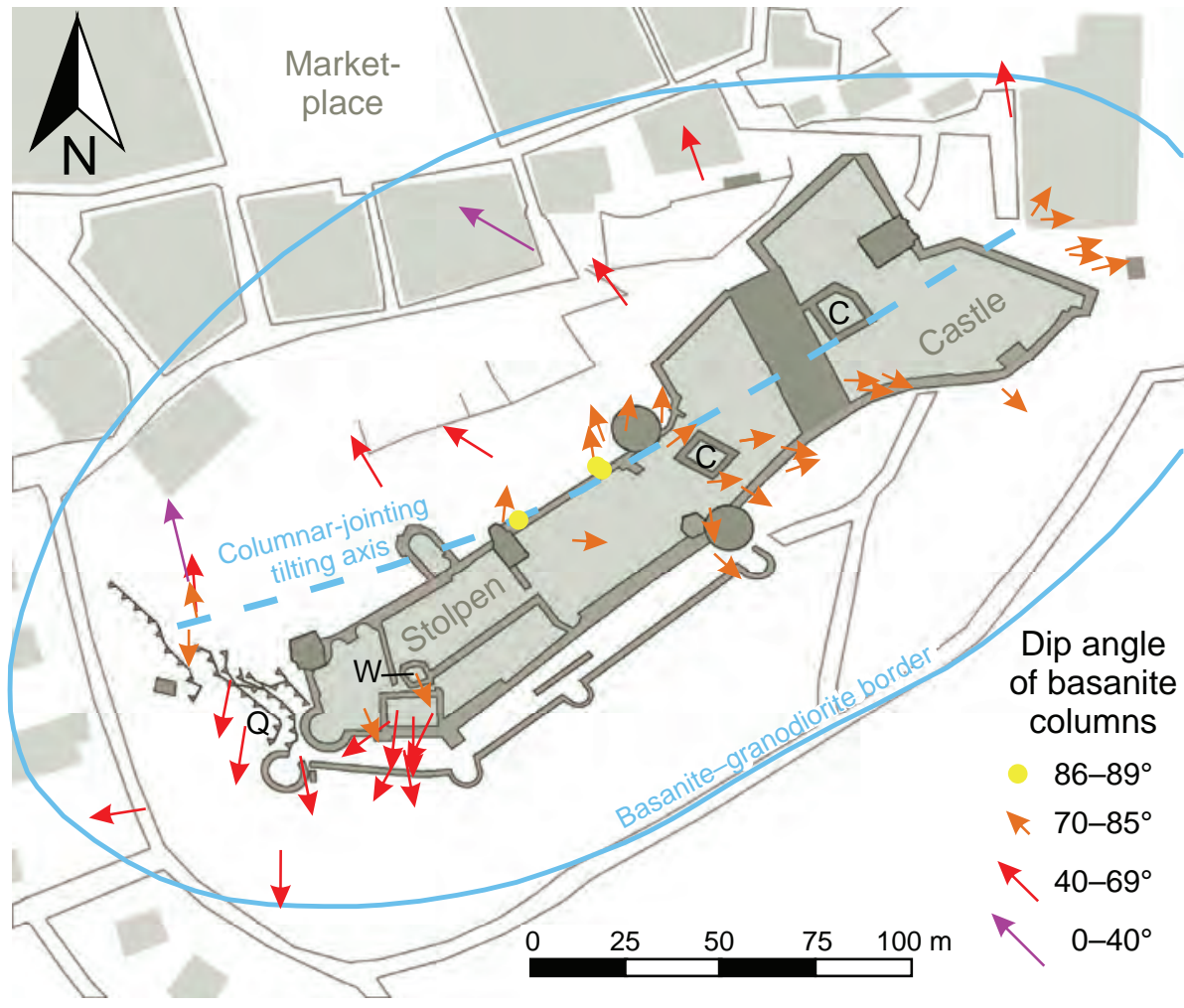
and mostly disaggregated into olivine-clinopyroxene clusters.

The outcropping Castle Hill lavas show very variable contents of rock-forming minerals. The plagioclase vanishes in some samples, while the nepheline content increases. In three out of the fifty investigated thin sections, no plagioclase can be observed and the nepheline content reaches up to 45 vol. \%, suggesting that this rock must be termed nephelinite. In these three samples, clinopyroxene represents the other main constituent (up to 65 vol. \%). Additionally, small

Fig. 6 Orientation of basaltic columnar jointing at the Stolpen Castle Hill (dip angle and dip direction of linear structures). C - cistern, W - castle well, Q - abandoned quarry. 

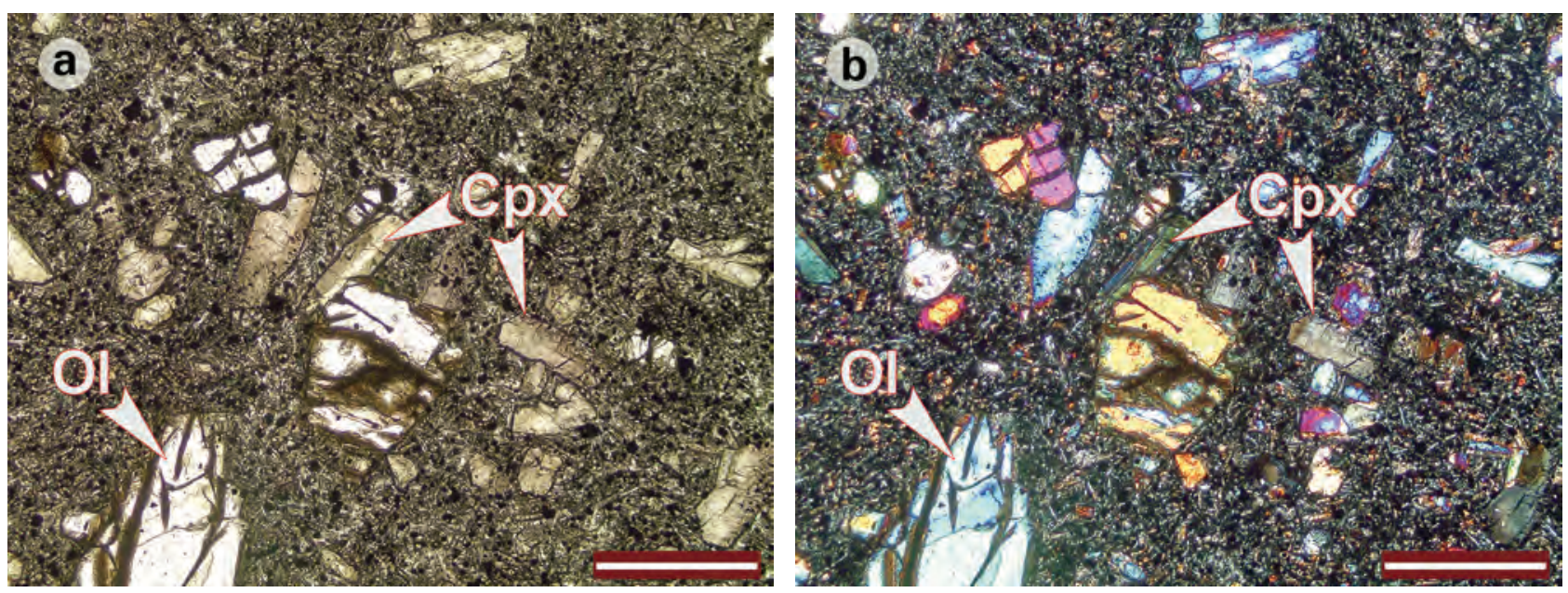

Fig. 7 Thin section of a typical basanitic Stolpen lava with phenocrysts of olivine (Ol) and clinopyroxene (Cpx) in a micro-crystalline groundmass Bars are $0.5 \mathrm{~mm}$ long (a - plane-polarized light, PPL; $\mathbf{b}$ - crossed nicols, XPL).

amounts of olivine and opaque minerals occur $(<2$ vol. \%).

Collectively, considering its mineralogical content, the Stolpen lava can be classified as basanite with tendencies towards nephelinite, which is a typical rock type of the Lausitz Volcanic Field (Büchner et al. 2015). The classification of the whole-rock chemistry, shown in the total alkalis-silica (TAS) diagram (Fig. 8), supports this observation. The five analysed samples plot together with five literature data in the basanite/tephrite field. Finally, the high content of olivine allows a more specific classification as basanite.

Moreover, nephelinite enclaves (in a broader sense of Didier and Barbarin 1991) were observed in seven thin sections of the basanite (Figs 9a-d). They are $1-10 \mathrm{~mm}$ in size and contain mainly clinopyroxene, olivine and nepheline. Plagioclase is missing, while opaque minerals are rare or absent. Nephelinite enclaves are often rimmed by opaque minerals but can also be distinguished by their different crystal size (Fig. 9a-b). They have a microcrystalline texture and resemble the above-described nephelinite samples.

Fig. 8 Total Alkalis-Silica (TAS) diagram for volcanic rocks from the Stolpen Volcano (see the legend) in comparison with 76 samples from the Lausitz Volcanic Field (Büchner et al. 2017).
Granodiorite xenoliths and quartz xenocrysts represent a further typical phenomenon. They can often be observed in thin sections (Koch et al. 1983), but xenoliths up to $1 \mathrm{~m}$ across were historically found also in outcrops (Geinitz 1882). The thin sections clearly show intense metasomatic overprinting of granodioritic xenoliths by the basanite lava. Such an overprint can be identified by opaque alterations caused by Fe-Mn impregnations, the separation of brownish glass, the new growth of skeletal potassium feldspar crystals (Fig. 10) and/or the magmatic corrosion of the quartz xenocrysts with a regular microcrystalline clinopyroxene corona (Koch et

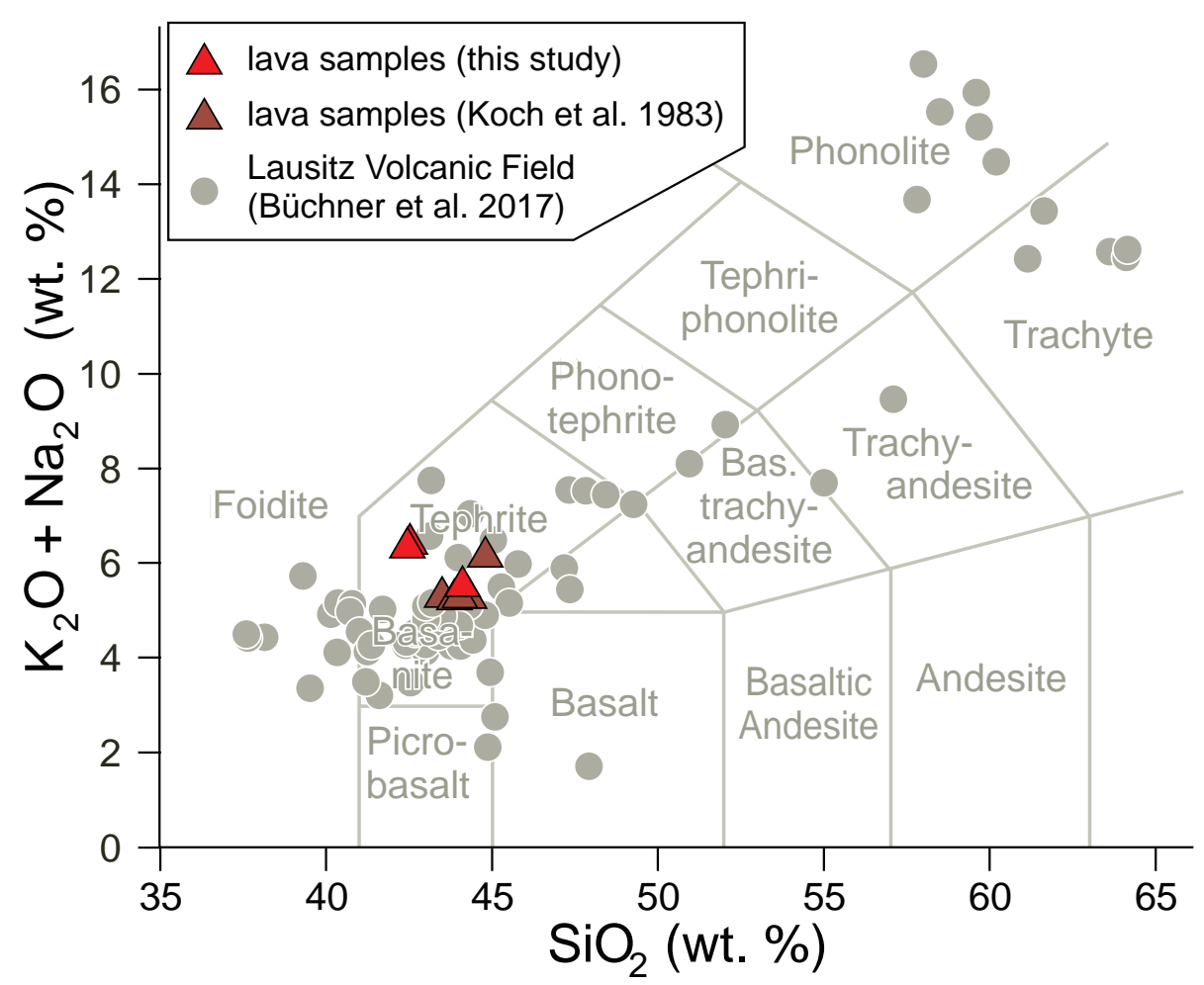



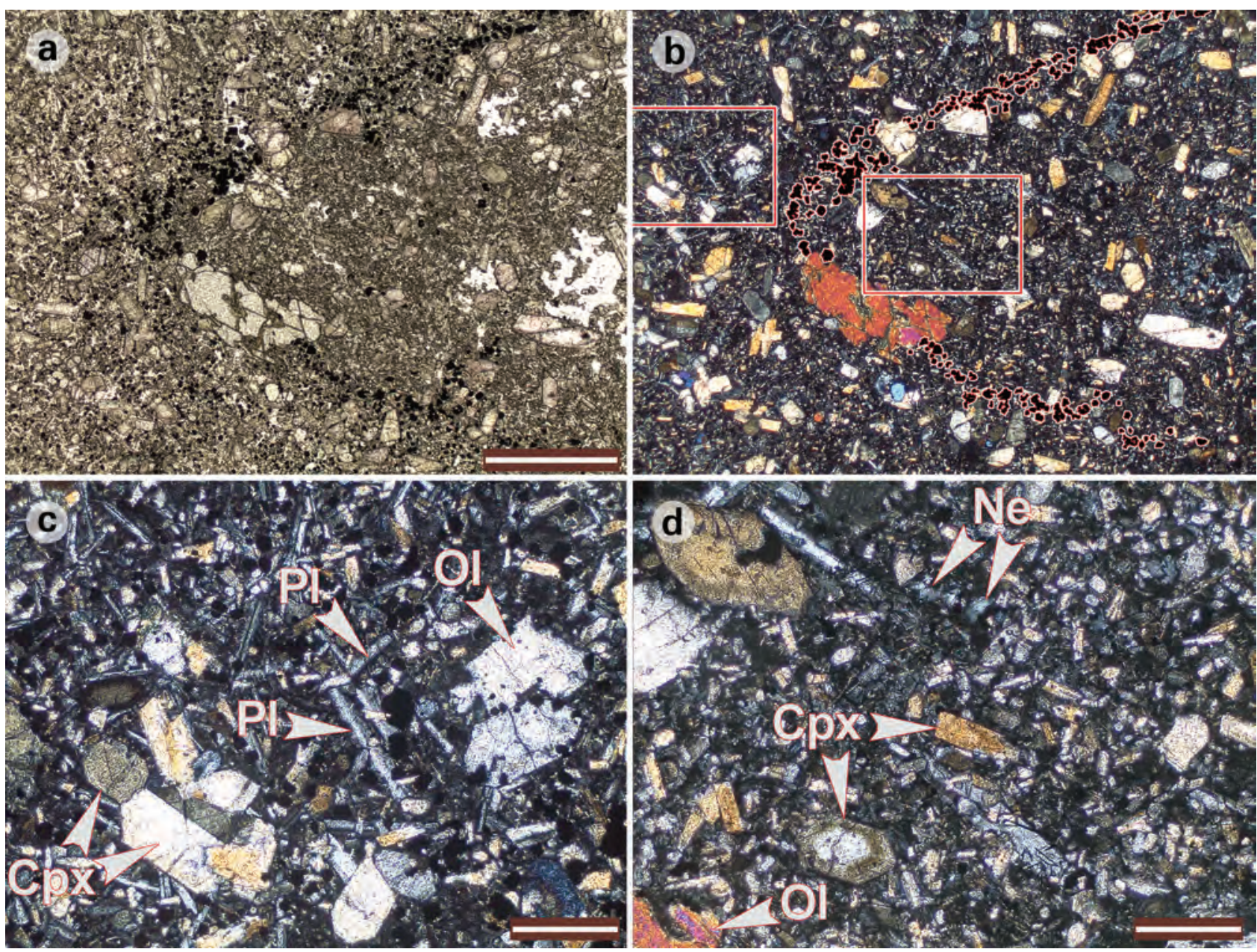

Fig. 9 Thin section of nephelinite enclaves in basanite. Overview ( $a-b)$ and detailed micro photographs $(\mathrm{c}-\mathrm{d})$ ): $\mathbf{a}-$ Distinct contact rimmed by an opaque mineral (black; PPL); b - Contact outlined by red-white lines (XPL); the position of the close-up photographs of Figs 9a (left) and 9b (right) is also shown. Bar is $1 \mathrm{~mm}$ long; $\mathbf{c}$ - Basanite with plagioclase laths ( $\mathrm{Pl}$ ); $\mathbf{d}$ - Nephelinite (Ne) with nepheline in interstitial spaces. Additionally marked phenocrysts are olivine $(\mathrm{Ol})$ and clinopyroxene $(\mathrm{Cpx})$. Crossed nicols. Bars are $0.2 \mathrm{~mm}$ long.

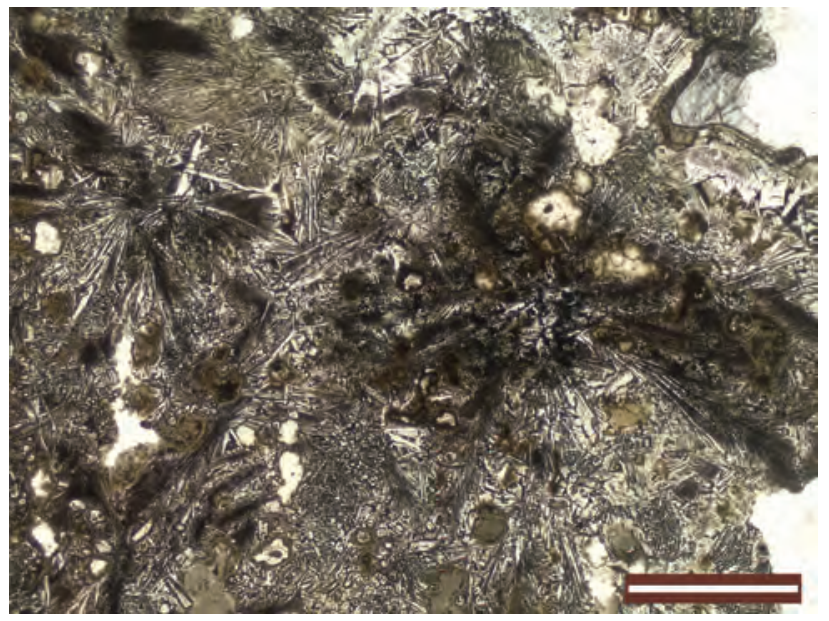

Fig. 10 Granodiorite xenolith with skeletal growth of potassium feldspar which has been overprinted by basanite lava. Thin section image with plane-polarized light and $1.0 \mathrm{~mm}$ bar. al. 1983). These mantled quartz xenocrysts are termed quartz ocelli and reflect magma mixing (hybridism) after Vernon (1991).

\subsection{Whole-rock geochemistry}

The geochemical data for different rock samples are given in Tab. 1. Beside three unaltered lava samples, two pyroclastic rocks have been analysed. Sample 17/3/141 represents a large scoria fragment while $17 / 1 / 31-2$ is the ash matrix from the same scoria tuff breccia deposit. Weathering of both pyroclastic rocks is indicated by their high LOI (over 19 wt. \%). In contrast, LOI of the unaltered lavas is $1.5 \mathrm{wt}$. \%.

Major-element contents of the unaltered lava samples show slight dissimilarities (Tab. 1). $\mathrm{SiO}_{2}$ content varies slightly from 42.5 to $44.1 \mathrm{wt}$. \%, while each of 


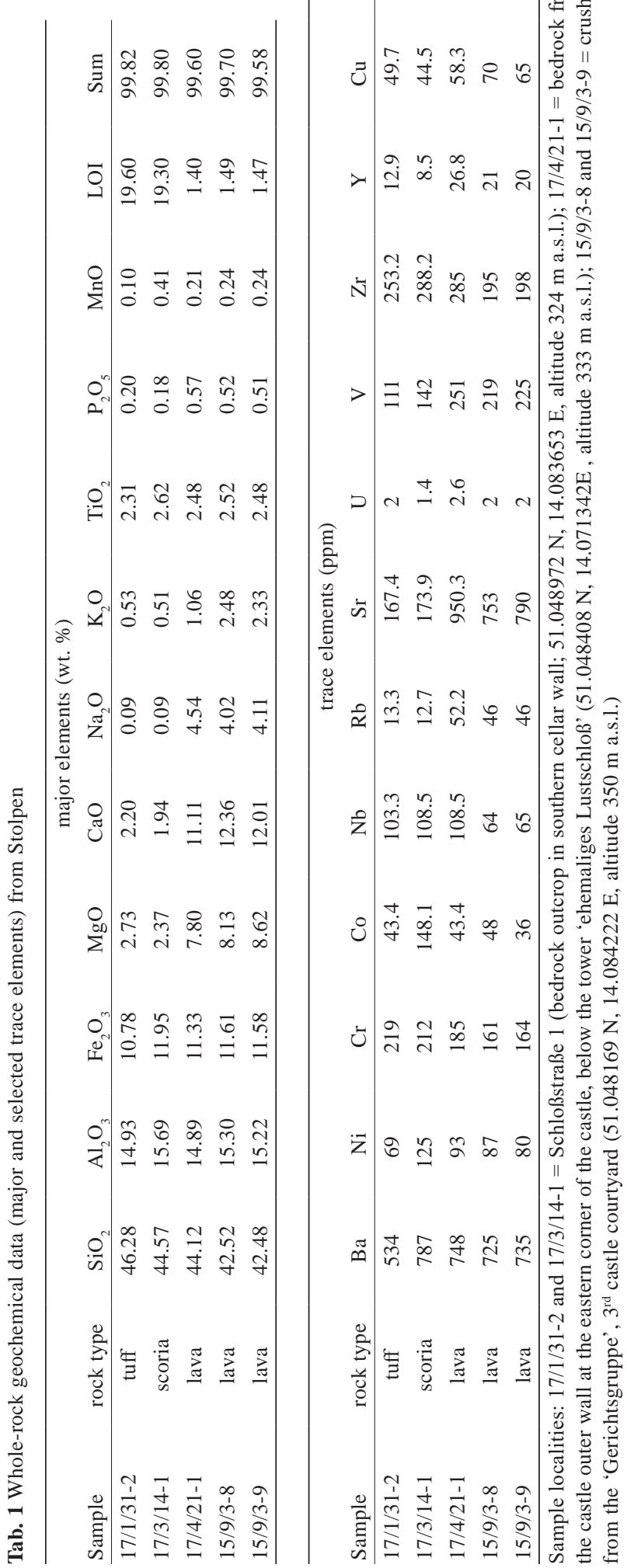

the alkalis vary more strongly (e.g., $\mathrm{K}_{2} \mathrm{O}$ from 1.1 to 2.5 wt. \%).

Trace-element concentrations show a similar variation. The $75 \%$ difference in the content of compatible elements between scoria sample (17/3/14-1, $148 \mathrm{ppm} \mathrm{Co}$ ) and lava (17/4/21-1, $36 \mathrm{ppm}$ Co) is particularly noteworthy. Nickel content varies from 80-93 ppm in lava to 125 ppm in scoria.

\section{Discussion}

\subsection{Volcanology}

The measurements of basaltic columnar jointing orientations provide important information for the reconstruction of non-outcropping contacts between the lava and country rock (DeGraff and Aydin 1987). The low dipping angles that are particularly flat at the north-western margin of the basaltic lava formation, suggest a steep contact surface between the lava body and its granodiorite surroundings. The correlation of this fact with the radial outward inclination of the basaltic columns (Fig. 6) indicates a steep ellipsoidal boundary of the lava body.

Basalt columns in the castle well can be traced without gaps for over c. $85 \mathrm{~m}$ (von Charpentier 1778). Dips of columnar jointing start at the top of the well with a steep $75^{\circ}$ angle and decline towards the base where they show an inclination of $60^{\circ}$ SSE (Eulitz in Theile 1884). The column orientation in the well offers no indications of a feeder dyke position as described by Geinitz (1982) and Klemm (1890; profile section 2). The moderate dipping of basaltic columns at the base of the well implies a gradual ascent of the basal contact plane of the basaltic lava towards SSE. This correlates well with the position of the tilting axis of the convergent columnar jointing structure, which runs $30 \mathrm{~m}$ north of the well (see Fig. 6).

Using the geological map (Fig. 3) and this additional information, two geological cross sections were constructed to reveal the structure of the volcano (Fig. 11). This shows that the base of the basaltic body is over $50 \mathrm{~m}$ deeper than the present outcropping granodiorite country rock at the foot of the Stolpen Hill. This is fundamental for the reconstruction and indicates a significant deepening of the basalt body base into the granodioritic basement. This situation can be best interpreted as the lava lake of a maar crater (according to Lorenz et al. 2003). Therefore, the geological features at the Stolpen Castle Hill allow the construction of a maar-diatreme volcano (e.g., White and Ross 2011).

A unique characteristic of the volcano is that lava lake filling started with a small scoria cone at the northern margin of the maar crater (analogous to the Crater Elegante in Mexiko; Gutmann 2002), which was later 


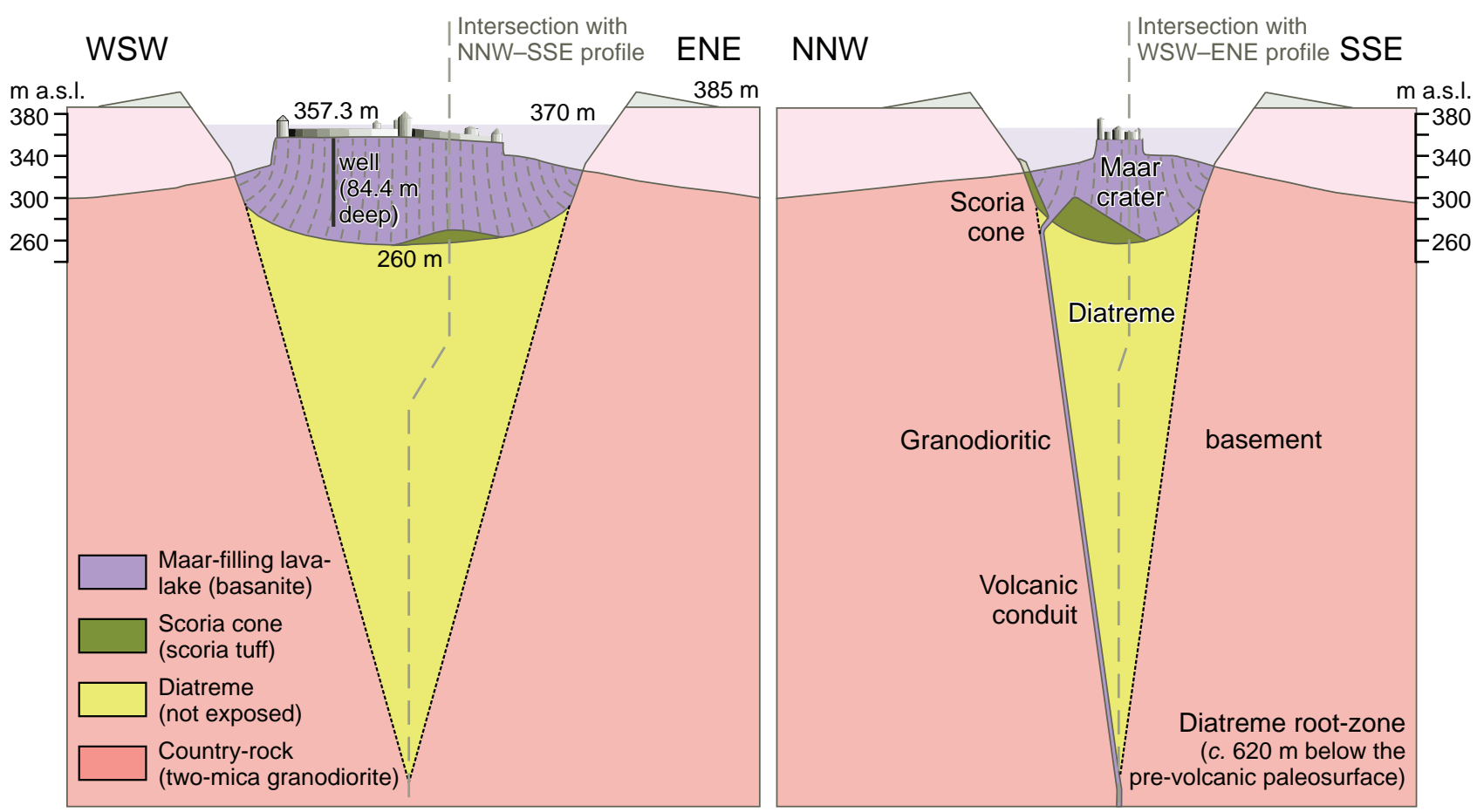

Fig. 11 Geological cross sections of the structure of the Stolpen Volcano. Beside the recent situation (vivid colours), denudated parts since the time of active volcanism (pale colours), are also shown. Profile positions can be seen in Fig. 3.

flooded by upwelling lava. It is very likely that effusive processes destroyed large parts of the scoria cone. The lighter scoriae floated to the surface of the lava lake and only some remnants remain preserved at the maar crater margin today. Some isolated scoriae can still be found in the lava, while large amounts of scoriae near the lava lake surface have since eroded.

Unfortunately, no direct volcanological material evidence of the diatreme phase, such as diatreme breccia or tuff ring remnants, is known to exist. Diatreme breccia deposits may still be buried below the basaltic lava body, while all tuff ring remnants must have been completely eroded over time (Figs 11 and 12). However, only a diatreme phase model provides a coherent explanation for the existence of a basaltic lava body with the dimensions of $340 \times 180 \times c .110 \mathrm{~m}$, which is lowered at least $50 \mathrm{~m}$ below the granodioritic framework (for dimensions, see Figs 3 and 11). Furthermore, the orientation of basaltic columnar jointing ultimately shows a radial outward dip starting in the center of the basaltic hill. This requires a concentric cavity in the granodiorite basement, the outer contact surface of which dips at an angle of at least $50-75^{\circ}$. The columns are oriented perpendicular to this (steeply dipping) contact surface (see Fig. 6, ESM 2 and literature on basalt column dips in Sections 1 and 3.1). Consequently, it is possible to exclude an interpretation as a lava flow because outcrops of the basalt-granodiorite contact margin all lie at the same erosion level and basalt column dips show a radial orientation, in contrast to a valley-like longitudinal orientation.

An explanation as a lava lake from a scoria cone would only be possible if the base line of the volcano was shifted down at the time of volcanism by the formation of a pit crater as result of a phreatomagmatic eruption after an initial scoria cone phase (after Riedel et al. 2003; see also Büchner and Tietz 2012). In this case a thick scoria bed must occur between the surrounding country rock and the lava lake. However, the contact area between the granodioritic country rock and the basaltic lava lake found during the mapping, is apparently rather narrow (Fig. 3). Only one enclosure of a scoria tuff of a few meters in thickness was observed between the two geological units. The contact between the granodiorite country rock and the basaltic lava must be mostly direct, since these are the only circumstances under which large rocks could tumble down from the steep crater walls into the lava lake, explaining the occurrence of large granodioritic xenoliths (for more details see below).

Alternative explanation, that the lower part of a plug inside a vent (e.g., as intrusion in an explosion breccia) was eroded to a shallow subvolcanic level, is not applicable because the scoria deposits imply a subaerial positioning of the volcano. Plugs may be formed within loose sediments or tephra, for example, within a scoria cone. However, the country rock of the Stolpen Volcano is igneous so it could not be displaced in the same way 


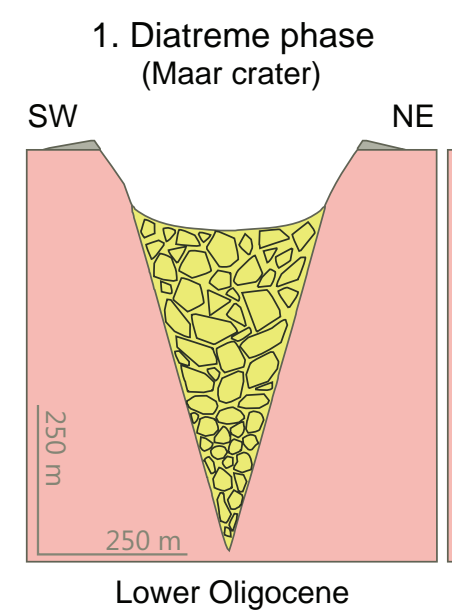

(c. $30 \mathrm{Ma}$ )
2. Scoria cone phase (Maar-filling lava-lake) 3a. Post-volcanic phase
(geogenic exhumation) 3b. Post-volcanic phase (anthropogenic overprint)

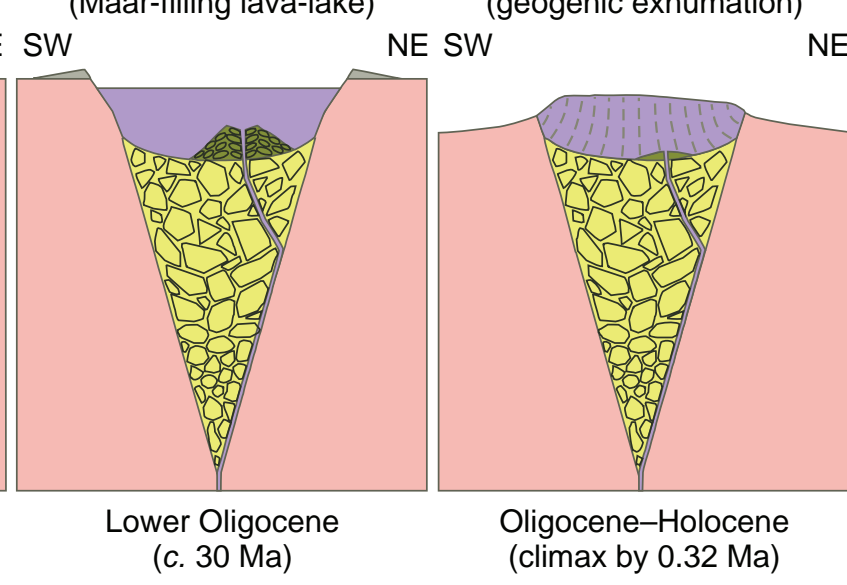

E SW

$\mathrm{NE}$

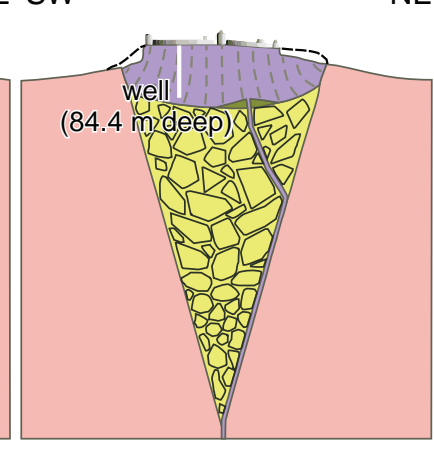

Holocene

(0.001 Ma-recent)

Fig. 12 Schematic sequence of the Stolpen Volcano development in three phases, deduced from the geological map and profile sections (Figs 3 , 11). For the legend see Fig. 11.

as unconsolidated rocks, a process which would be necessary to create enough space for a plug-like intrusion.

Another alternative interpretation could be the formation of a pit crater that was caused by the sinking (or collapse) of the surface lying above an emptied magma chamber. However, such subsidence or collapse craters only occur in large central volcanoes, such as the Hawaiian shield volcanoes. Explosive volcanic pipes formed by gas-rich lava, such as kimberlites, can in principle occur in crystalline country rock but such volcano types are unknown in the Cenozoic Central European Volcanic Province. Therefore, the proposed maar-diatreme model currently offers the best explanation for the genesis of the Stolpen Volcano.

Based on this model and the volcanological profile reconstruction of the volcano edifice, the genesis of the Stolpen Volcano can be divided into three phases: (I) diatreme formation, (II) scoria cone emergence, and (III) exhumation of the volcano structure (Fig. 12). Consequently the volcanic evolution of the Stolpen Volcano shows a progressive change in eruption style from phreatomagmatic (phase I) to magmatic explosive and, finally, effusive processes (both last phase II). The evolution is likely best explained by a single volcanic episode without significant time gaps between eruption stages, which is typical of magmatic explosive and effusive processes. A Strombolian eruption always starts with a magmatic explosive stage and the formation of a scoria cone. Sometimes explosiveness decreases continuously during the eruptive phase due to magma degassing. Nonfragmented liquid lava then fills the crater or lava flows are produced (e.g., Pioli et al. 2008 for the eruption of the Parícutin Volcano/Mexico 1943-1952).

However, time gaps between the initial phreatomagmatic and final Strombolian stages are very common (e.g., Kereszturi et al. 2010). In case of the Stolpen
Volcano, this period was likely of a negligible duration. A short time gap is assumed because a relatively high number of large granodiorite xenoliths in the lava lake indicate steep and unstable (fresh) maar crater margins. An alternative explanation of such large xenoliths as a result of the ascent of non-explosive lava against gravity is not reasonable. At the time of lava lake filling, the maar crater slopes were in a juvenile stage and excessively steep, making them susceptible to mass collapse resedimentation (Kurszlaukis and Fulop 2013). Therefore, progressive widening of the crater to a mature stage with a smooth relief and low potential energy can probably be excluded in case of the Stolpen Volcano.

The Stolpen Volcano can be genetically classified as a complex monogenetic volcano (Kereszturi and Németh 2012) or, concerning its eruption history, as a maar/ scoria cone/lava lake (fig. 6 in Kereszturi and Németh 2012). In addition, according to its architecture, the Stolpen Volcano consists of a 'hybrid' edifice, which can be described as an intra-maar scoria cone with lava flow (Kereszturi and Németh 2012). The classification chart of external vs. internal controlling parameters for monogenetic volcanism (fig. 4 in Smith and Nemeth 2017) categorizes the Stolpen Volcano as a mixed-type volcano with tendency to phreatomagmatic dominated volcanos (type 4: well-developed phreatomagmatic landform with a magmatic infill). This type stands out as more affected by external control factors such as water than magmaticdominated volcanoes. Therefore, the Stolpen Volcano is moderately dependent on the elevation of the landscape and climatic conditions which control ground water level and quantity. This indicates that the genesis of the Stolpen Volcano took place during a time of low ground levels (peneplain) and voluminous aquifers (humid-tropical climate), conforming well with the explanations given by Tietz and Büchner (2015). 
The Stolpen scoria inclusions are particularly well preserved and therefore suitable for further volcanological investigations. Lautze and Houghton (2007) studied scoria textures of different eruption phases from Stromboli, Italy. They distinguished between high-density (HD) scoria with $\sim 45-50 \%$ bulk vesicularity (with $\sim 70-80 \%$ of the cavities being vesicles larger than 1.5 $\mathrm{mm}$ ) and low-density (LD) scoria with $\sim 70-75 \%$ bulk vesicularity (with about a third of the cavities being large vesicles). According to Lautze and Houghton (2007), the density and vesicle size distribution of the Stolpen scoriae (especially in isolated lava inclusions) allows a classification as HD pyroclasts. This type of pyroclasts indicates a longer residence time of magma in shallow conduits that are associated with passive degassing, greater magma viscosity and infrequent, relatively weak explosions (Lautze and Houghton 2007). The absence of large quantities of mantle xenoliths also suggests an interrupted magma ascent. This interpretation of the eruption intensity of the Stolpen corresponds well with the results of Polacci et al. (2006). Their study included a comparison of scoriae from Mt. Etna, Italy, that were produced under Strombolian and Hawaiian eruption regimes. Even considering these investigations, the Stolpen scoriae definitely correspond to a Strombolian eruption style. In contrast to the Hawaiian-style fire fountain scoria deposits, the investigated Strombolian scoriae from Mt. Etna show a lower vesicularity of 52-56 \% (compared to 53-74\% Hawaiian-style vesicularity), indicating stronger volatile depletion and a longer residence time before the eruption. It is noteworthy that Strombolian scoria vesicles are analogous to Stolpen scoriae in that they are larger in size (up to $>10 \mathrm{~mm}$ ) and of lower vesicle number density. Following Polacci et al. (2006), some features of the Stolpen scoria texture indicate mild to strong Strombolian eruptions with weak effusive activities, which makes a violent Hawaiian-style fire fountain eruption with high lava effusion rates rather unlikely. In contrast to Stolpen, the in situ scoria tuff discovery indicated by high ash content (60-70 vol. \%) together with some host rock material suggests a violent Strombolian eruption (Cashmann and Scheu 2015) with possible involvement of phreatomagmatic episodes. Large scoria bombs of up to $20 \mathrm{~cm}$ in size indicate a proximal position of this outcrop (cellar Schloßstraße 1), though investigated scoria inclusions in the lava do not present any records of such powerful eruptive episodes. This may be as a result of fragmentation processes of LD scoria inclusions in the lava. Lighter scoriae probably floated to the surface of the lava lake, accumulated and have since been eroded.

Mapping and profile reconstruction of the Stolpen Volcano (Figs 3 and 11) enable the estimation of morphometric parameters, such as the shape of the maar crater, the depth of the maar diatreme volcano structure, the maar crater length-to-depth ratio, as well as the former volume of the maar crater lava lake. The diameter of the diatreme at the base of the maar crater is $150 \mathrm{~m}$ in the shortest (NNW-SSE) and $300 \mathrm{~m}$ in the longest (WSW-ENE) directions (Fig. 11). The obviously elongated shape of the diatreme and the overlying maar crater must have been the result of the granite tectonics. The orientation of the main granodiorite fracture planes in the Stolpen area provide evidence because they are WSW-ENE aligned (Müller and Behr 1968, fig. 10 in Müller et al. 2001). The best rock divisibility $s$, behind the perpendicular direction of $k$ and $l$, is of great economic interest for the extraction of rock blocks in the Lausitz granite quarries (Müller et al. 2001). Hence, the ground water supply and therefore also phreatomagmatic expansion of the diatreme structure were significantly controlled and shaped by the rock divisibility from WSW to ENE.

The inclination of the cone-shaped diatreme wall consistently amounts to almost identical dip angles of $80-85^{\circ}$ (average $82^{\circ}$; Lorenz et al. 2003). Therefore, calculations based on the smallest diameter of the diatreme yield a diatreme depth of $600 \mathrm{~m}$ below the present-day summit of the Stolpen Castle Hill. Since the structure must end at the same depth, the outer diatreme contact must feature a somewhat flatter inclination of $c .74^{\circ}$ (Fig. 11). Given that the minimum diatreme depth has been calculated, the actual diatreme could reach somewhat deeper into the ground.

According to the profile reconstruction, the accumulated width of the Stolpen maar crater together with the tephra ring should total $430 \mathrm{~m}$ in SW-NE and $280 \mathrm{~m}$ in NW-SE directions, with an average width between the tephra ring crest of $355 \mathrm{~m}$ (Fig. 11). Assuming that the height of the tephra ring was $15 \mathrm{~m}$ (which cannot be proven), the depth of the maar crater can be estimated at $140 \mathrm{~m}$. This gives a crater diameter-to-depth ratio of about 2.5. According to data for 15 Quaternary maar craters with ratios between 3 and 7 (fig. 14 in Ross et al. 2011), this estimated ratio is relatively low (or the crater is rather relatively deep). However, calculated ratios are mostly modified by post-eruptive fillings of the crater and/or erosion of the tephra rim, which both lead to a decrease in crater height (for further comparison see Pirrung et al. 2008). Furthermore, the crater diameter quoted in literature is not always reliable since, in most cases, the authors mean the outer margin of the tephra ring and not the tephra crest itself. The ratio may therefore be lower than stated by Ross et al. (2011). Head et al. (1981) presented lower ratios of 2-5, meaning that the calculated crater diameter-to-depth ratio of 2.5 from Stolpen is potentially realistic.

The depth of the basaltic lava lake is estimated at $110 \mathrm{~m}$ in the center of the maar crater. This is a minimum 
value as the lava lake surface has since been eroded and the deepest lava lake contact has never been observed. The depth of the castle well $(85 \mathrm{~m})$ was taken as an initial fixed value, with an estimated $10 \mathrm{~m}$ added as depthextension to reach the bottom of the maar crater and $12.7 \mathrm{~m}$ added to the top of the well to attain the former lava lake level above the recent hill top (Fig. 11). It would be unrealistic to assume greater thickness of the lava lake since this would mean a diameter-to-depth ratio of the maar crater even lower than 2.5, which would no longer correspond to the ratios determined by Ross et al. (2011). Given the estimated depth of $110 \mathrm{~m}$, the minimal volume of the basaltic lava lake exclusive of any lava outflow can be calculated at $4.9 \times 10^{6} \mathrm{~m}^{3}$. According to de Silva and Lindsay (2015), this is a small maar crater lava lake filling as maar crater volumes typically range between 1 and 400 (maximum 2,500) $\times 10^{6} \mathrm{~m}^{3}$. For example, the Hungarian Bondoró maar-diatreme volcano in the Bakony-Balaton Highland Volcanic Field (which produced effusive basaltic lava outflows) has a calculated volume of $c .115 \times 10^{6} \mathrm{~m}^{3}$ and is referred to as a small-volume polycyclic basaltic volcano (Kereszturi et al. 2010).

These calculations of the former geometry of the Stolpen Volcano allow estimating the uplift and erosion rates from the onset of active volcanism, both around the Stolpen area and the adjacent SW Lausitz Block. The elevation of the pre-volcanic surface (based on the recent altitude) can be estimated at 385 m a. s. l. (Fig. 11). This elevation is 15 meters higher than the assumed lava lake surface and 27.7 meters higher than the highest point of the present day Castle Hill. Considering the maar crater diameter-todepth ratio (see above), the lava lake level should not be any higher than assumed in Fig. 11. However, it is not possible to determine whether lava flowed

Fig. 13 Reconstruction of the landscape evolution of the Stolpen Volcano area with geological cross section (above) and relief shading map (below, with profile position). The cross section shows the recent morphology (vivid colours) beside the assumed level of the paleosurface at the time of volcanism, at $c .30 \mathrm{Ma}$. This allows the calculation of an uplift and denudation value of $100-150 \mathrm{~m}$ until today. The profile section is $5 \times$ exaggerated. Produced using a topographic map with scale $1: 50,000$ and DEM 2 data of the State Survey Office of Saxony. out of the crater because all potential lava flows would have been completely eroded by now. If lava flows had existed, the pre-volcanic surface may have been lower than presumed, at about $370 \mathrm{~m}$ a. s. l. The amount of eroded material can be calculated assuming that uplift was constantly balanced by denudation and that the former surface of the land was nearly flat and horizontal (Tietz and Büchner 2015). Close to the Stolpen Volcano, the surface has been lowered via erosion by 65 meters. This can be determined from the difference in height between the pre-volcanic land surface $(385 \mathrm{~m})$ and the highest position of the granodiorite country rock (320 m), which can still be encountered. However, this adjacent rock in the shelter of the remnant volcano hill is higher than its surrounding area. Its lowest point is located 1500 meters SW where the Letschwasser River discharges into the Wesenitz River (235 m a. s. l.), while its highest point can be found 1500 meters NE in a granodiorite saddle, close to the road between Stolpen and Lauterbach (285 $\mathrm{m}$ a. s. l.). This leads to an estimated erosion of $100-150 \mathrm{~m}$ since the most recent active volcanism ( 30 Ma) (Fig. 13). In the case of lava outflows the minimum height of the maar crater $(370 \mathrm{~m})$ can be reduced by 15 meters. This enables the calculation of average uplift and denudation rates of $3.3-5.0 \mathrm{~mm} / \mathrm{kyr}$ (minimum 2.8-4.5 mm/kyr). According to Tietz and Büchner (2015)
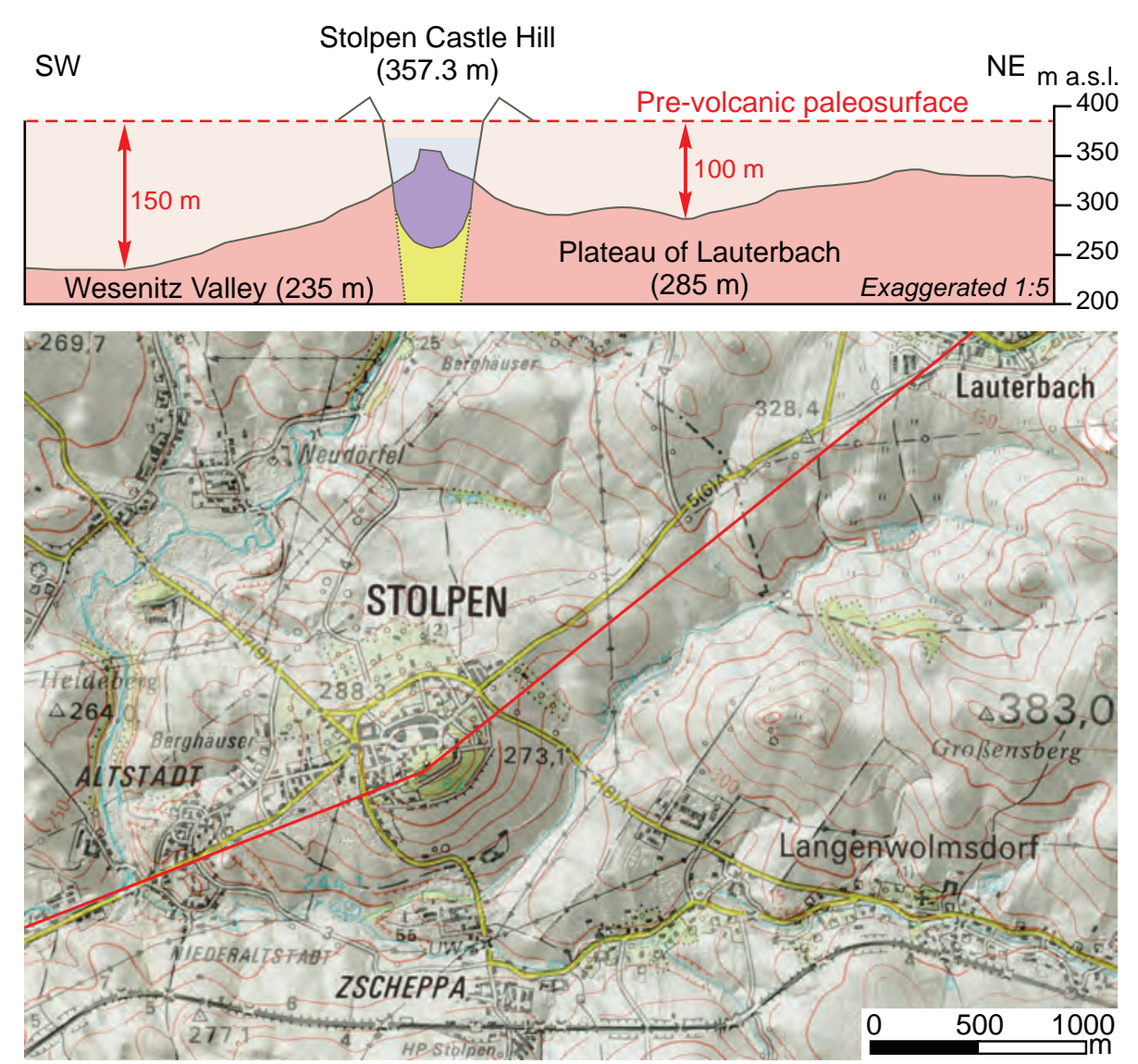
comparable uplift and denudation rates existed for the same time span in the eastern Lausitz Block near Görlitz ( $3 \mathrm{~mm} / \mathrm{kyr}$ ) and the Zittau Mountains immediately south of the southern Lausitz Block (2-3 mm/kyr). In contrast, the values estimated by temperature-time paths of apatite fission-track ages in the Lausitz Block are very high with an erosion of 3,000-3,500 $\mathrm{m}$ and a calculated denudation rate of $100 \mathrm{~mm} / \mathrm{kyr}$ for the age between 85 and $50 \mathrm{Ma}$ (Lange et al. 2008). Tietz and Büchner (2015) showed that the main uplift since volcanism took place immediately after the Elsterian glacial in the Middle Pleistocene (at $c$. $320 \mathrm{ka}$ ). It is likely that the neotectonic movements of the Lausitz Block had already started by 1.3 Ma (Wenger et al. 2017), which would lead to an uplift and denudation rate of 77-115 mm/kyr (minimum 65-105 mm/kyr) for the Stolpen area.

\subsection{Petrography and geochemistry}

The investigated Stolpen lava samples implicate an inhomogeneous lava body given the combined observations of (1) incorporated melt enclaves of chemically different but genetically associated lava, and (2) inclusions of country rocks or their fragments. Magmatic enclaves are the result of incomplete magma mixing (Didier and Barbarin 1991) and represent a common phenomenon in large lava bodies in the Lausitz Volcanic Field (Wenger et al. 2017, see also Rapprich et al. 2017). These cognate enclaves (sensu Didier and Maury 1991) imply diverse magmatic sources for the Stolpen magma likely induced by fractionation below the surface, or independent magma batches. The comparison of trace-element systematics between scoria fragments and the uppermost parts of the lava appears to indicate magmatic fractionation. The lava represents the last erupted material of the Stolpen Volcano, whereas the scoria fragments correspond to the initial stage of the Strombolian phase. Early eruptions brought the more primitive magmas (probably nephelinites) to the surface, with later eruptions likely emptying the magma chamber and leading to the effusion of already slightly fractionated lava (basanites). This process is manifested in decreased contents of compatible elements such as $\mathrm{Ni}$, Co and $\mathrm{Cr}$. However, the data are insufficient to quantify the extent of fractionation and to clarify the conditions in the magma chamber. The mingling features and short time gap between the phreatomagmatic and final magmatic effusive phases also support a coexistence of two contrasting magma batches. Based on present data it is not possible to clarify whether the fractionation or two-source model better explains the origin of Stolpen magma. Further analyses of pyroclastics and different melt portions in the lava lake are thus necessary. This could also elucidate the role played by magma mingling during the initial ascent from the magma chamber and, by inference, the eruption.
The intense reaction between the basanite lava and granodioritic inclusions indicates contamination of the lava. In addition to the magma mingling processes, incorporation of granodioritic components (e.g. quartz) leads to an overprint apparent in silica content and probably in whole-rock geochemistry. This represents an additional reason for the wide range of data in Fig. 8. Assimilation of country rock is also documented in the trace-element contents of the tuff sample. This is because of phreatomagmatic influence during the formation of the scoria cone and numerous granodioritic xenoliths included by the ash-bearing pyroclastics. This led to a decrease in compatible elements relative to scoria fragments. But more geochemical data would be necessary for more precise discussion.

However, it can be established that the Stolpen lava lake was heterogeneous in composition and that the rocks are dominated by basanites. The Stolpen lava thus cannot be described as basalt according to current nomenclature (Le Maitre 2002). The example of Stolpen clearly demonstrates that historical rock type localities cannot always be easily unified with present-day rock nomenclature. Furthermore, it is unreasonable to use local rock localities to define type localities as they often show local transitions or convergences. Homogeneous rock bodies occur rarely or not at all in nature, especially over a wider area.

\section{Conclusions}

The present study provides a reconstruction of the Stolpen Volcano, adapted from new field-based observations, basaltic column inclination measurements and geographic parameters, such as topography and the information derived from the $84.4 \mathrm{~m}$ deep castle well. The finds of a scoria tuff outcrop and numerous inclusions of isolated scoriae in the studied lava are important, because they indicate that a scoria cone was formed by a superficial eruption of a 'real' volcano. Therefore, the previous model for the Stolpen Volcano as a subvolcanic lava- or cryptodome must be corrected.

Based on new investigations, the Stolpen Volcano can be interpreted as a maar-diatreme volcano with a maarfilling basanitic lava lake. There is a clear distinction between a volcanic (c. $30 \mathrm{Ma}$ ) and a post-volcanic phase. The initial diatreme phase (phase 1) included a heavy phreatomagmatic eruption, forming a maar crater of c. $430 \times 280 \mathrm{~m}$. However, no sediment deposits have been found from this stage. Possible deposits of this phase are the tuff ring (that would now be completely eroded) or diatreme breccias that may still be buried at greater depths. Immediately after the initial phase, a change in the eruption style occurred, resulting in an episode of 
Strombolian activity (with no ground water supply) and the presumed formation of a small scoria cone (phase 2 ). Only a local remnant at the northern margin of the maar crater provides evidence of this volcano edifice. Finally, the maar crater was filled almost completely by basanitic lava, forming a lava lake with a depth of $\sim 110$ $\mathrm{m}$. Neotectonic uplift of the investigated area has since c. 1.3 Ma exposed the basaltic lava lake body at the surface. The uplifted basaltic hill overtops the recent granite landscape by $40-60 \mathrm{~m}$ (phase 3a). Hence, the Stolpen Castle Hill is a typical example of a topographic relief inversion. Recent anthropogenic activity has overprinted the shape of the mountain from fairly round to a narrow ridge (phase $3 b$ ). The flat and elongated mountain plateau is a remnant of the former lava lake surface and was used as the basement of the castle.

None of the volcanic phases were interrupted by a significant time gap, but magmatic activity changed in eruption style from phreatomagmatic to Strombolian with explosive and effusive stages. Due to the changes in eruption style and related volcanic phases the Stolpen Volcano can be classified as a complex monogenetic volcano.

The petrographic and geochemical investigations reveal that the rock at Stolpen Castle Hill is basanite trending to nephelinite, a typical rock type of the Lausitz Volcanic Field. Also taking into account that large parts of the Stolpen lava rock show inhomogeneity, the Stolpen Castle Hill is, in a scientific sense, not a suitable type locality for basalt or basanite. However, the outcrops of volcanic rocks as well as the historical and scientific importance, undoubtedly give Stolpen relevance as a type locality for volcanic rocks.

Acknowledgements. The authors thank Werner Förster and many more house owners from Stolpen, Eberhard Henschel (Stolpen building yard), Jürgen Major and Jens Gaitzsch (Stolpen Castle administration) for their friendly support. Appreciation also goes to Alison Seidel (Kiel, Germany) and Erik Wenger (Görlitz, Germany) for their support with fieldwork and during the creation of a map from columnar dipping measurements. Michael Ude (Jena, Germany) kindly performed geochemical analysis of two samples. Nora Krebs (Freiberg, Germany) and Adam Stewart (Lancaster, United Kingdom) helped to improve the English, which we gratefully appreciate. Freya Wilke (Görlitz, Germany) is thanked for preparation of thin sections. We are also grateful to Peter Suhr (Dresden, Germany) whose valuable remarks eminently contributed to a previous version of this manuscript. We thank Tomáš Magna and Vladislav Rapprich (Prague, Czech Republic) for editorial handling, comments and patience throughout the development of this manuscript. Many thanks are due also to Vladislav Rapprich recasting the graphic images into vector files and Vojtěch Janoušek for the technical and linguistic review of the final manuscript. Finally we want to express our gratitude to Jaromír Ulrych (Prague, Czech Republic) and two anonymous reviewers whose critical and comprehensive remarks helped to greatly improve the quality of the paper.

Electronic supplementary material. Supplementary tables with measurements of size/texture of scoria inclusions and orientation of columnar jointing in the Stolpen lava are available online at the Journal web site (http://dx.doi. org/10.3190/jgeosci.275).

\section{References}

Agricola G (1546) De natura fossilium lib. X. H. Froben, Basel. In: Prescher H (ed) Georgius Agricola: De natura fossilium libri X. Die Mineralien (translated in German and edited by G. Fraustadt in connection with H. Prescher) Gedenkausgabe des Staatlichen Museums für Mineralogie und Geologie zu Dresden, Issue IV. VEB Deutscher Verlag der Wissenschaften, Berlin, 1958, pp $1-548$

BüChner J, Tietz O (2012) Reconstruction of the Landeskrone Scoria Cone in the Lusatian Volcanic Field, Eastern Germany - long-term degradation of volcanic edifices and implications for landscape evolution. Geomorphology 151/152: 175-187

Büchner J, Tietz O, Viereck L, Suhr P, Abratis M (2015) Volcanology, geochemistry and age of the Lausitz Volcanic Field. Int J Earth Sci 104: 2057-2083

Büchner J, Tietz O, Tietz A, Scholle T (2017) Ist der Basalt ein Sachse? Wissenschaftshistorische, petrographische und geochemische Untersuchungen am Burgberg Stolpen, der Typlokalität für Basalt seit 1546. Ber Naturforsch Gesell Oberlausitz 25: 127-142

Cashman KV, Scheu B (2015) Magmatic fragmentation. In: Sigurdsson H, Houghton BF, McNutt SR, Rymer H, Stix J (eds) The Encyclopedia of Volcanoes. Academic Press, London, pp 459-471

DeGrafF JM, AYdin A (1987) Surface morphology of columnar joints and its significance to mechanics and direction of joint growth. Geol Soc Am Bull 99: 605-617 DE SILVA S, LindSAY JM (2015) Primary volcanic landforms. In: Sigurdsson H, Houghton BF, McNutt SR, Rymer H, Stix J (eds) The Encyclopedia of Volcanoes. Academic Press, London, pp 273-297

DIDIER J, BARBARIN B (1991) The different types of enclaves in granites - nomenclature. In: DIDIER J, BABARIN B (eds) Enclaves and Granite Petrology. Developments in Petrology 13, Elsevier, Amsterdam, pp 19-23

Didier J, MAury RC (1991) The outstanding contribution of Alfred Lacroix to the study of enclaves in magmatic rocks. In: DIDIER J, BABARIN B (eds) Enclaves and Gra- 
nite Petrology. Developments in Petrology 13, Elsevier, Amsterdam, pp 25-32

GeINITZ HB (1882) Die geologische Beschaffenheit der Umgebung von Stolpen in Sachsen. Sitz-Ber Abh Naturwiss Gesell Isis Dresden, Abh 1882: 91-126 [chapter "Basalt", pp 113-119]

Goтн K, Suhr P (2007) “Der Basalt ist ein Sachse” Der Basaltschlot des Burgberges von Stolpen in der Lausitz. In: Look E-R, Feldmann L (eds) Faszination Geologie. Die bedeutendsten Geotope Deutschlands. Schweizerbart, Stuttgart, pp 88-89

GutmanN JT (2002) Strombolian and effusive activity as precursors to phreatomagmatism: eruptive sequence at maars of the Pinacate Volcanic Field, Sonora, Mexico. J Volcanol Geotherm Res 113: 345-356

Head JW, Sparks RS, Bryan WB, Walker GPL, Greely R, Whitford-Stark JL, Guest JE, Wood CA, Shultz PH, CARR MH (1981) Distribution and Morphology of Basalt Deposits on Planets. Basaltic Volcanism on the Terrestrial Planets. Pergamon Press, New York, pp 701-800

Hofmann M, Voigt T, Bittner L, Gärtner A, Zieger J, Linnemann U (2018) Reworked Middle Jurassic sandstones as a marker for Upper Cretaceous basin inversion in Central Europe - a case study for the U-Pb detrital zircon record of the Upper Cretaceous Schmilka section and their implication for the sedimentary cover of the Lausitz Block (Saxony, Germany). Int J Earth Sci 107: 913-932

Janetschke N, Niebuhr B, Wilmsen M (2015) Interregional sequence-stratigraphical synthesis of the Plänerkalk, Elbtal and Danubian Cretaceous groups (Germany): CenomanianeTuronian correlations around the Mid-European Island. Cretaceous Res 56: 530-549

KeresZturi G, NÉMeth K (2012) Monogenetic basaltic volcanoes: genetic classification, growth, geomorphology and degradation. In: NÉMETH K (ed) Updates in Volcanology - New Advances in Understanding Volcanic Systems. InTech, Rijeka, pp 3-89

Kereszturi G, Csillag G, Németh K, Sebe K, Kadosa B, JÁGER V (2010) Volcanic architecture, eruption mechanism and landform evolution of a Plio/Pleistocene intracontinental basaltic polycyclic monogenetic volcano from the Bakony-Balaton Highland Volcanic Field, Hungary. Cent Eur J Geosci 2: 362-384

KLEMM G (1890) Geologische Specialkarte des Königreichs Sachsen - Section Stolpen, Blatt 68. Giesecke \& Devrient, Leipzig, 1 map with 2 profiles

KLEMM G (1892) Erläuterungen zur geologischen Specialkarte des Königreichs Sachsen -Section Stolpen, Blatt 68. W. Engelmann, Leipzig, pp 1-34

Koch EA, Pfeiffer L, Stammler L, Beeger D (1983) Der Basalt von Stolpen in der Lausitz. Abh Staatl Mus Mineral Geol Dresden 32: 1-144
Kurszlaukis S, Fulop A (2013) Factors controlling the internal facies architecture of maar-diatreme volcanoes. Bull Volcanol 75: 761-773

LANGe J-M, TONK C, Wagner GA (2008) Apatitspaltspurdaten zur postvariszischen thermotektonischen Entwicklung des sächsischen Grundgebirges - erste Ergebnisse. Z Dt Ges Geowiss 159: 123-132

LAUTZE NC, Houghton BF (2007) Linking variable explosion style and magma textures during 2002 at Stromboli volcano, Italy. Bull Volcanol 69: 445-460

Le Maitre RW (ed) (2002) Igneous Rocks: A Classification and Glossary of Terms. Recommendations of the International Union of Geological Science Subcommission on the Systematics of Igneous Rocks, $2^{\text {nd }}$ ed. Cambridge University Press, Cambridge, pp 1-236

LoRenz V, SuHr P, Goth K (2003) Maar-Diatrem-Vulkanismus - Ursachen und Folgen. Die Guttauer Vulkangruppe in Ostsachsen als Beispiel für die komplexen Zusammenhänge. Z geol Wiss 31: 267-312

MÜller B, BeHr H-J (1968) Der Granit von Stolpen und seine Beziehungen zum Strukturbild der Westlausitz. Freiberg Forsch H C 241: 87-96

Müller A, MÜLler B, BeHR H-J (2001) Structural contrasts in granitic rocks of the Lusatian Granodiorite Complex and the Erzgebirge, Germany - in commemoration of Hans Cloos. Z geol Wiss 29: 521-544

Pioli L, Erlund E, Johnson E, Cashman K, Wallace P, Rosi M, Delgado-Granados H (2008) Explosive dynamics of violent Strombolian eruptions: the eruption of Parícutin Volcano 1943-1952 (Mexico). Earth Planet Sci Lett 271: 359-368

Pirrung M, Büchel G, Lorenz V, Treutler H-C (2008) Post-eruptive development of the Ukinrek East Maar since its eruption in 1977 A.D. in the periglacial area of south-west Alaska. Sedimentology 55: 305-334

Polacci M, Corsaro RA, ANDronico D (2006) Coupled textural and compositional characterization of basaltic scoria: insights into the transition from Strombolian to fire fountain activity at Mount Etna, Italy. Geology 34: 201-204

Pfeiffer L, Kaiser G, Pilot J (1984) K-Ar-Datierung von jungen Vulkaniten im Süden der DDR. Freiberg Forsch H C 389: 93-97

RaPprich V, SHiElds S, HaLOdová P, LindLINE J, van WyK de Vries B, Petronis MS, Valenta J (2017) Fingerprints of magma mingling processes within the Miocene Zebín tuff cone feeding system (Jičín Volcanic Field, Czech Republic). J Geosci 62: 215-229

Riedel C, Ernst GGJ, Riley M (2003) Controls on the growth and geometry of pyroclastic constructs. J Volcanol Geotherm Res 127: 121-152

Ross P-S, Delpit S, Haller MJ, Németh K, Corbella $H$ (2011) Influence of the substrate on maar-diatreme volcanoes - an example of a mixed setting from the Pali 
Aike volcanic field, Argentina. J Volcanol Geotherm Res 201: 253-271

SCHOLLE T (1994-2017) Kartierungen zu den Basalt- und Granodioritaufschlüssen. Unpublished Report, Ingenieurbüro Dr. Thomas Scholle, Stolpen, pp 1-30

Schubert G (1972) Eine basaltreiche jungpleistozäne Hangschuttdecke bei Stolpen (Oberlausitz). Abh Berichte Naturkundemus Görlitz 47: 33-35

SMITH IEM, NÉMETH K (2017) Source to surface model of monogenetic volcanism: a critical review. In: NÉMETH K, Carrasco-NúÑez G, Aranda-Gómez JJ, Smith IEM (eds) Monogenetic Volcanism. Geological Society, London, Special Publications 446: pp 1-28

TheiLE F (1884) Der Brunnen der Burg Stolpen. Über Berg und Thal 7: 238-240

Tietz O, Büchner J (2015) The landscape evolution of the Lausitz Block since the Palaeozoic - with special emphasis to the neovolcanic edifices in the Lausitz Volcanic Field (Eastern Germany). Z Dtsch Ges Geowiss 166: $125-147$

TIETZ O, BüChNER J (2018) Editorial: The origin of the term 'basalt'. J Geosci 63: 295-298
Tikhomirova M (2002) Zircon inheritance in diatexite granodiorites and its consequence on geochronology - a case study in Lusatia and the Erzgebirge (Saxo-Thuringia, eastern Germany). Chem Geol 191: 209-224

VERNON RH (1991) Interpretation of microstructures of microgranitoid enclaves. In: DidIER J, BABARIN B (eds) Enclaves and Granite Petrology. Developments in Petrology 13, Elsevier, Amsterdam, pp 277-291

Vogel W, KuIPERS G (1987) A pre-calibrated program for geological applications. Phillips New Developments in X-Ray Spectrometry 11: 2-8

von ChaRPENTIER JFW (1778) Mineralogische Geographie der Chursächsischen Lande. Crusius, Leipzig, pp $1-432$

Wenger E, Büchner J, Tietz O, Mrlina J (2017) The polycyclic Lausche Volcano (Lausitz Volcanic Field) and its message concerning landscape evolution in the Lausitz Mountains (northern Bohemian Massif, Central Europe). Geomorphology 292: 193-210

White JDL, Ross P-S (2011) Maar-diatreme volcanoes: a review. J Volcanol Geotherm Res 201: 1-29 